\title{
DYMANICS OF FORMATION OF FOREST CENOSES ON THE FALLOWS (Western Trans-Baikal, Buryat Republic, Russia)
}

\author{
Alexander Sizykh ${ }^{1 *}$, Victor Voronin ${ }^{1}$, Alexander Gritsenyuk ${ }^{2}$ \\ ${ }^{1}$ Siberian Institute of Plants Physiology and Biochemistry of RAS SB, 664033 Irkutsk, 132 Lermontova str., Russia; \\ ${ }^{2}$ V.R. Filippov Buryat State Academy of Agriculture, 670024 Ulan-Ude, 1 Pushkina str., Russia; \\ *Corresponding Author Alexander Sizykh e-mail: alexander.sizykh@gmail.com;
}

Received March 2020; Accepted May 2020; Published June 2020;

DOI: https://doi.org/10.31407/ijees10.224

\begin{abstract}
Studies of the peculiarities of vegetation structural-dynamic organization on post-agrarian landscapes in the Western Trans-Baikal allowed to establish modern trends of reconstitution of grasses (in the steppes) coenoses and the vector of formation of forest ones (at the initial stage of development) during last decades - since lands ploughing up for agricultural plants and use of the territories for pasturage had stopped. Land use in a region with relatively dry periods during different years at elevated anthropogenic pressure results in considerable destructions of soil and vegetation cover. The studied area is situated within the most important biogeographic boundaries, within the boundaries of regions and provinces of southern boreal forests and zonal dry bunchgrass steppes of Central Asian type. Degrading of the environment under such conditions is more manifested and vegetation reconstitution here is a long process in time and space. Recently there are trends of forests reconstitution on the lands ploughed up before and in the sites used during many years for pasturage. Steppificated spare stands of pine with cereals and motley grasses form, this is initial stage of forests of zonal type formation. There can be a constraint of forests formation on the fallows such as probable increase of anthropogenic impact, mainly pasturage accompanied periodically with burning (fire) on the background of climate changes determining the vector of formation of environmental conditions in the whole region.
\end{abstract}

Key words: forest coenoses, fallows, formation, Western Trans-Baikal. 